\title{
Factors controlling nitrous oxide at the microbial community and estuarine scale
}

\author{
Monique J. M. de Bie ${ }^{1}$, Jack J. Middelburg ${ }^{1, *}$, Mathieu Starink ${ }^{1}$, \\ Hendrikus J. Laanbroek ${ }^{2}$ \\ ${ }^{1}$ Netherlands Institute of Ecology, Centre for Estuarine and Marine Ecology, PO Box 140, 4400 AC Yerseke, The Netherlands \\ ${ }^{2}$ Netherlands Institute of Ecology, Centre for Limnology, Rijksstraatweg 6, 3631 AC Nieuwersluis, The Netherlands
}

\begin{abstract}
This paper examines the effect of oxygen on nitrous oxide $\left(\mathrm{N}_{2} \mathrm{O}\right)$ concentrations in estuarine waters. $\mathrm{N}_{2} \mathrm{O}$ has been measured year-round in the Schelde estuary, a high-nitrogen, lowoxygen macrotidal system. $\mathrm{N}_{2} \mathrm{O}$ concentrations were above atmospheric equilibrium levels indicating that this estuary represents a source to the atmosphere. The distribution of $\mathrm{N}_{2} \mathrm{O}$ showed consistent and systematic relationships with distribution patterns of ammonium, oxygen, nitrite and nitrification activities. A controlled laboratory experiment with a natural bacterial community from the Schelde estuary revealed maximum $\mathrm{N}_{2} \mathrm{O}$ production to occur at oxygen concentrations of about $5 \mu \mathrm{M}$. This production was inhibited by acetylene, a nitrification inhibitor. Maximum $\mathrm{N}_{2} \mathrm{O}$ concentration in the field occurred at oxygen concentrations below $35 \mu \mathrm{M}$. The difference in the oxygen concentration that results in maximum $\mathrm{N}_{2} \mathrm{O}$ may have arisen because low-oxygen environments present in the estuary were destroyed by stirring in our laboratory experiment. It appears that low oxygen concentrations in estuarine water trigger enhanced $\mathrm{N}_{2} \mathrm{O}$ production if ammonium is present in sufficient amounts. This conclusion is further illustrated by data from the Thames, Loire and Gironde estuaries.
\end{abstract}

KEY WORDS: Nitrous oxide $\cdot$ Nitrification · Oxygen · Ammonium • Estuary $\cdot$ Scheldt $\cdot$ Thames $\cdot$ Loire $\cdot$ Gironde

\section{INTRODUCTION}

Nitrous oxide $\left(\mathrm{N}_{2} \mathrm{O}\right)$ affects the global climate in 2 ways (Bange 2000). In the lower atmosphere, $\mathrm{N}_{2} \mathrm{O}$ acts as a greenhouse gas that is more than 100 times more powerful in warming potential than $\mathrm{CO}_{2}$. $\mathrm{N}_{2} \mathrm{O}$ is chemically stable in the troposphere and reaches the stratosphere where it forms NO radicals in photochemical reactions that are involved in the destruction of ozone; hence, $\mathrm{N}_{2} \mathrm{O}$ contributes indirectly to the destruction of the ozone layer. Atmospheric mixing ratios of $\mathrm{N}_{2} \mathrm{O}$ have been increasing steadily over the past $100 \mathrm{yr}$ (Battle et al. 1996). The accumulation of the gas in the atmosphere is the result of unbalanced sources and sinks of $\mathrm{N}_{2} \mathrm{O}$. Aquatic systems, both salt- and fresh-

${ }^{*}$ Corresponding author. E-mail: middelburg@cemo.nioo.knaw.nl water, contribute 25 to $30 \%$ of the total global $\mathrm{N}_{2} \mathrm{O}$ emission (IPCC 1996). Estuaries are calculated to account for approximately $60 \%$ of total marine $\mathrm{N}_{2} \mathrm{O}$ production/emission (Bange et al. 1996). To understand the biogeochemistry of $\mathrm{N}_{2} \mathrm{O}$ in estuaries, both quantification of $\mathrm{N}_{2} \mathrm{O}$ concentrations and fluxes, and understanding of factors controlling the production of $\mathrm{N}_{2} \mathrm{O}$ are necessary.

In aquatic systems, $\mathrm{N}_{2} \mathrm{O}$ can be produced during both nitrification and denitrification (Codispoti et al. 1992, 2001). The first step of nitrification, the oxidation of ammonia to nitrite, can be a source of $\mathrm{N}_{2} \mathrm{O}$, in particular under low oxygen concentrations (Goreau et al. 1980, Jørgensen et al. 1984, Anderson \& Levine 1986, Stüven et al. 1992, Kester et al. 1997). The concentration range of oxygen, under which significant quantities of $\mathrm{N}_{2} \mathrm{O}$ per unit volume are produced, is very narrow. At oxygen concentrations higher than this critical range, oxi- 
dation to nitrite and subsequently nitrate is completed with only modest net production of $\mathrm{N}_{2} \mathrm{O}$, while the ammonium oxidation reaction does not occur at all at oxygen concentrations close to 0 and below the range for $\mathrm{N}_{2} \mathrm{O}$ production (Codispoti et al. 1992). Besides this oxidative pathway, $\mathrm{N}_{2} \mathrm{O}$ may also be formed in the reductive process of denitrification. During denitrification, nitrate is reduced to molecular nitrogen gas $\left(\mathrm{N}_{2}\right)$ via the intermediates $\mathrm{NO}_{2}, \mathrm{NO}$ and $\mathrm{N}_{2} \mathrm{O} . \mathrm{N}_{2} \mathrm{O}$ reduction is, at least in some denitrifying species, more sensitive to oxygen than the other reduction steps (Betlach \& Tiedje 1981, Zumft \& Kroneck 1990). This can lead to accumulation of $\mathrm{N}_{2} \mathrm{O}$ at low oxygen concentrations, in particular during periods with alternating, transient conditions (Naqvi et al. 2000). Oxygen concentration apparently has a strong regulating influence on $\mathrm{N}_{2} \mathrm{O}$ production. Additionally, ammonia concentration, nitrite concentration, $\mathrm{pH}$, the physical environment and the physiological characteristics of the microbial community determine the amount and extent of the eventual emission of $\mathrm{N}_{2} \mathrm{O}$ to the atmosphere. The overall factors controlling $\mathrm{N}_{2} \mathrm{O}$ production and emission seem to be dependent on the specific conditions and the system studied, and may vary temporarily.

At the global scale, $\mathrm{N}_{2} \mathrm{O}$ production and emission from riverine and coastal systems has been related to $\mathrm{N}$ loading (Seitzinger \& Kroeze 1998). Similarly, the main factor controlling $\mathrm{N}_{2} \mathrm{O}$ emission from estuarine sediments is N load (Seitzinger \& Nixon 1985, Middelburg et al. 1995).

At the level of isolated populations (Goreau et al. 1980, Anderson \& Levine 1986, Anderson et al. 1993) and natural communities (Jørgensen et al. 1984), oxygen is governing $\mathrm{N}_{2} \mathrm{O}$ yield during nitrification and denitrification. Consistent with these laboratory studies, Yoh et al. (1983) reported accumulation of $\mathrm{N}_{2} \mathrm{O}$ in oxygen-deficient layers of freshwater lakes, and Naqvi et al. (2000) reported enhanced $\mathrm{N}_{2} \mathrm{O}$ production in a low oxygen zone of the Indian continental shelf. There appear to be different controlling factors of $\mathrm{N}_{2} \mathrm{O}$ production at different scales, with nitrogen loading governing $\mathrm{N}_{2} \mathrm{O}$ at the global and across ecosystem scales, and oxygen being the key factor in laboratory studies and within individual aquatic ecosystems. Moreover, the temporal variability in oxygen and ammonium and/or nitrate availability may be another factor in natural systems. Transient events rather than long-term steady-state conditions have been proposed to govern $\mathrm{N}_{2} \mathrm{O}$ production (Naqvi et al. 2000).

In this study, we present a seasonal study of $\mathrm{N}_{2} \mathrm{O}$ concentrations in the Schelde estuary, a high-nitrogen, low-oxygen macrotidal system. Furthermore, a natural community from the Schelde estuary was used in controlled laboratory experiments to identify the controlling factor of $\mathrm{N}_{2} \mathrm{O}$ production. These field and experi- mental data will be used to argue that oxygen is the controlling factor provided that ammonium is abundant. Finally, we present dissolved $\mathrm{N}_{2} \mathrm{O}$ data for a number of additional macrotidal European estuaries (Thames, Loire and Gironde) to strengthen our arguments.

\section{MATERIALS AND METHODS}

Research areas. Samples were collected in the context of BIOGEST, an EU-supported program on biogeochemical processes and trace-gas production in a number of European tidal estuaries (Middelburg et al. 2002). The Schelde estuary (also known as the Scheldt and Westerschelde) drains an estimated $21000 \mathrm{~km}^{2}$ of northern France, Belgium and The Netherlands, an area with approximately 10 million inhabitants and a nitrogen load of $5 \times 10^{9} \mathrm{~mol} \mathrm{~N} \mathrm{yr}^{-1}$ (Soetaert \& Herman 1995). Turbidity is high in the entire upper estuary, which is illustrated by the observed suspended matter concentrations (10 to $350 \mathrm{mg} \mathrm{l}^{-1}$ ). The Thames estuary is a turbid, tidal estuary on the east coast of the UK, entering the North Sea at Southend on Sea. The drainage area of the river Thames is rather small $\left(14000 \mathrm{~km}^{2}\right)$ but hosts a population of about 12 million, including London, and has a dissolved inorganic nitrogen load of $2.4 \times 10^{9} \mathrm{~mol} \mathrm{~N} \mathrm{yr}^{-1}$ (Trimmer et al. 2000). The river Loire drains a major part of central France and its estuary is well-mixed and very turbid with suspended matter concentrations over $1 \mathrm{~g} \mathrm{l}^{-1}$. The rivers Garonne and Dordogne that drain a large part of SW France feed the Gironde estuary. It is a well-mixed, highly turbid estuary with suspended matter concentrations over $1 \mathrm{~g} \mathrm{l}^{-1}$. The Thames, Loire and Gironde estuaries were studied only once in February 1999, September 1998 and June 1997, respectively. The Schelde estuary was examined at monthly resolution from April 1997 to April 1998.

$\mathrm{N}_{2} \mathrm{O}$ measurements. Dissolved $\mathrm{N}_{2} \mathrm{O}$ concentrations were measured in surface waters while sailing or on station using a continuous flow gas equilibrator connected to a photoacoustic gas analyser (Bruel \& Kjaer type 1302). This method has been described elsewhere (Abril et al. 2000, De Wilde \& De Bie 2000, Middelburg et al. 2002). Headspace gas concentrations were recalculated to water concentrations using the temperature- and salinity-dependent partitioning coefficient (Weiss \& Price 1980). The precision of dissolved $\mathrm{N}_{2} \mathrm{O}$ concentrations was better than $3 \%$ and the accuracy is based on calibration with certified standards traceable to the US National Institute of Standards.

Ancillary measurements. Salinity, temperature and oxygen were measured either with a CTD system, equipped with a polarographic oxygen sensor (THIS- 
HYDRO H2O) or obtained from Middelburg \& Nieuwenhuize (2000) and Middelburg et al. (2002). Nutrients were measured using automated colorimetric techniques (De Wilde \& De Bie 2000, Middelburg \& Nieuwenhuize 2000). Nitrification activity was measured by the ${ }^{14} \mathrm{C}$-bicarbonate incorporation method (Somville 1978). Briefly, carbon fixation by autotrophic ammonia-oxidising bacteria is quantified by the difference of inorganic carbon incorporation during incubation with and without $\mathrm{N}$-serve, a specific inhibitor of nitrification activity. These data have been discussed in detail by De Bie et al. (2002).

Incubation experiments. Estuarine waters with a salinity of 1 from the upper part of the Schelde estuary were collected in March to April 1998 and subsequently incubated in a $4 \mathrm{l}$ glass incubation vessel (3.5 1 water and 0.51 headspace) that was kept at in situ temperature $\left(10^{\circ} \mathrm{C}\right)$ by a cooling spiral connected to a water bath. The water was stirred by a magnetic stirrer and continuously bubbled with a gas mixture at $20 \mathrm{l} \mathrm{h}^{-1}$, of which the composition was accurately controlled by mass flow control valves (Brooks Instruments) connected to $\mathrm{N}_{2}$, air and acetylene bottles. Oxygen concentrations in the vessel were monitored by an oxygen electrode (ECOLAB, Maarssen, The Netherlands). Every 5 min, $\mathrm{N}_{2} \mathrm{O}$ concentration was monitored in the headspace using the photoacoustic gas analyser that was connected in a closed circuit to the vessel. Water samples could be taken by means of a syringe in the vessel lid, where a gas-tight valve prevented gas exchange.

At the start of the experiment, ammonium was added to a final concentration of about $2 \mathrm{mM}$, and the vessel was flushed with air until $100 \%$ air saturation and a steady state of $\mathrm{N}_{2} \mathrm{O}$ was reached. After that, oxygen concentration was stepwise brought down to $70,40,20,10,5,1$ and $0 \%$ air saturation by adjusting the incoming gas mixture until a new steady state of $\mathrm{N}_{2} \mathrm{O}$ concentration was established. Samples for ammonium, nitrite and nitrate were taken regularly. The total incubation lasted about $4 \mathrm{~d}$.

The experiment was repeated as described above, with the addition of $1 \%$ acetylene to the incoming gas mixture. Acetylene was purified by passing it through a trap containing sulphuric acid followed by a trap containing $5 \mathrm{M} \mathrm{NaOH}$ as according to Hyman \& Arp (1987). Acetylene is a known inhibitor of nitrification at low concentrations. At higher concentrations $(10 \% \mathrm{v} / \mathrm{v})$, it also inhibits the last step of denitrification, resulting in the accumulation of $\mathrm{N}_{2} \mathrm{O}$. The concentration of acetylene was monitored every 5 min using the photoacoustic analyser.

\section{RESULTS}

\section{Experiments}

Water from the upper Schelde estuary with its natural community was amended with ammonium, flushed with air until $100 \%$ saturation and subsequently incubated for $4 \mathrm{~d}$ while stepwise lowering imposed oxygen levels (Fig. 1). In the absence of acetylene, there was significant nitrification as reflected in increases in nitrate $\left(6.7 \pm 0.8 \mu \mathrm{M} \mathrm{h}^{-1}\right)$ and nitrite $(6.2 \pm$ $0.4 \mu \mathrm{M} \mathrm{h}^{-1}$ ) and a proportional decrease in ammonium $\left(-14.6 \pm 1.3 \mu \mathrm{M} \mathrm{h}^{-1}\right)$. In the presence of $1 \%$ acetylene, there was no significant decrease in ammonium, while nitrite and nitrate were consumed (Fig. 1C). Fig. 1
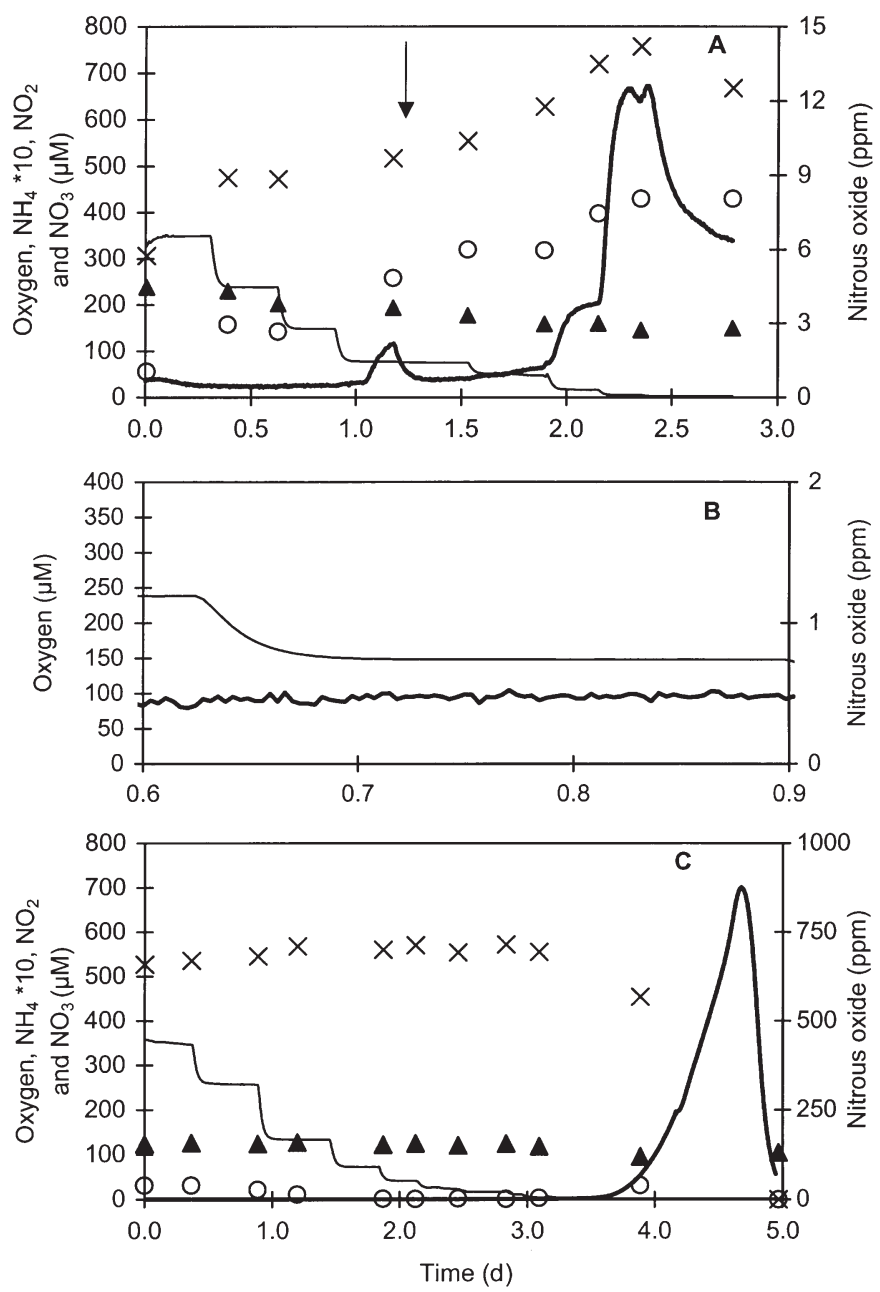

Fig. 1. Time evolution of oxygen (-), $\mathrm{N}_{2} \mathrm{O}(-)$, ammonium ( $(\boldsymbol{\Lambda})$, nitrate $(X)$ and nitrite $(O)$ during the laboratory incubations. (A) Incubation experiment without acetylene; (B) enlargement of the data presented in Panel A for the period of 0.6 to $0.9 \mathrm{~d}_{\text {i }}(\mathrm{C})$ incubation experiment with $1 \%$ acetylene. The arrow in Panel A indicates the period of malfunctioning of the stirring system resulting in transient accumulation of $\mathrm{N}_{2} \mathrm{O}$ 

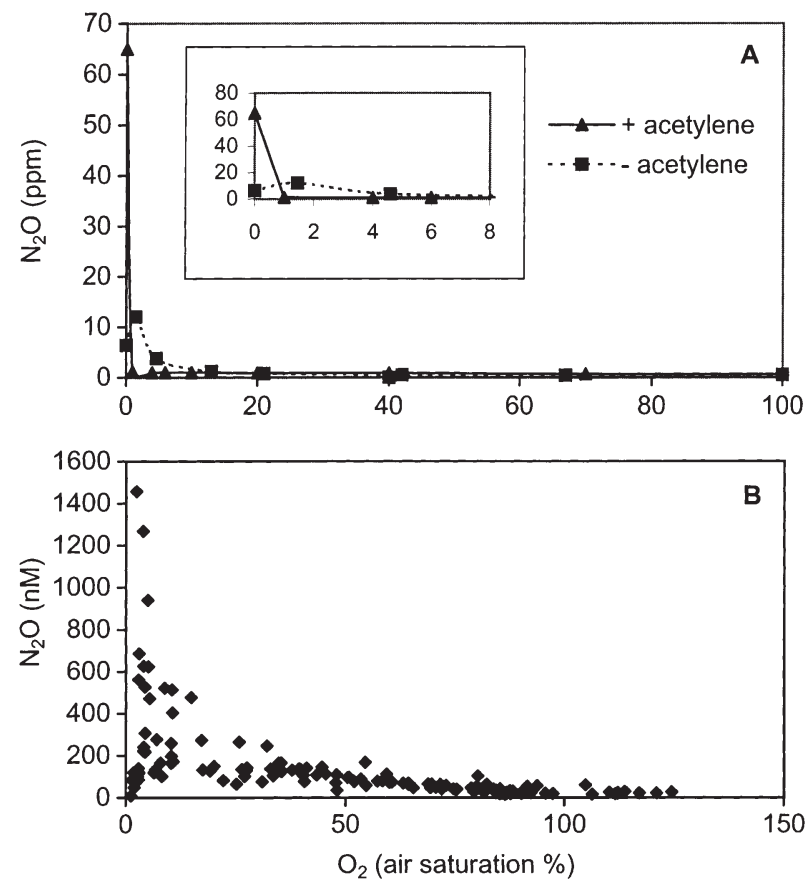

Fig. 2. (A) Steady-state $\mathrm{N}_{2} \mathrm{O}$ concentrations at different oxygen concentrations in the laboratory experiment with natural community. The inset shows an enlargement of the data in the oxygen range between 0 and $8 \%$ air saturation. (B) $\mathrm{N}_{2} \mathrm{O}$ versus dissolved oxygen in samples from the Schelde estuary

clearly shows that $\mathrm{N}_{2} \mathrm{O}$ production depends on the oxygen level and that it was predominantly formed at low oxygen concentrations. After imposing a new oxygen level, dissolved $\mathrm{N}_{2} \mathrm{O}$ concentrations reached an approximate steady-state level within 2 to $8 \mathrm{~h}$, which was dependent on conditions (Fig. 1A,B). Fig. 2A shows the steady-state $\mathrm{N}_{2} \mathrm{O}$ concentrations as a function of imposed oxygen levels. In the absence of acetylene, $\mathrm{N}_{2} \mathrm{O}$ concentrations were maximal at an oxygen concentration of about $5 \mu \mathrm{M}(1.5 \%$ air saturation; Fig. $2 \mathrm{~A})$, but $\mathrm{N}_{2} \mathrm{O}$ production occurred at all oxygen levels. At lower oxygen concentrations, $\mathrm{N}_{2} \mathrm{O}$ concentration decreased, although some $\mathrm{N}_{2} \mathrm{O}$ was produced even when oxygen was completely absent. In the presence of $1 \%$ acetylene, there was no maximum in $\mathrm{N}_{2} \mathrm{O}$ production at oxygen levels of about $5 \mu \mathrm{M}$ oxygen (1.5\% saturation). However, high $\mathrm{N}_{2} \mathrm{O}$ concentrations were observed under anoxic conditions. Acetylene is an inhibitor of the first step of nitrification (ammonium oxidation) and the last step of denitrification $\left(\mathrm{N}_{2} \mathrm{O}\right.$ reduction to dinitrogen). The absence of $\mathrm{N}_{2} \mathrm{O}$ production at low, non- 0 oxygen in the presence of the nitrification inhibitor acetylene provides evidence that nitrification is the major source of $\mathrm{N}_{2} \mathrm{O}$ in this experiment. The importance of nitrification was further illustrated by the immediate increase in concentration of $\mathrm{N}_{2} \mathrm{O}$ upon addition of ammonium (Fig. 3).

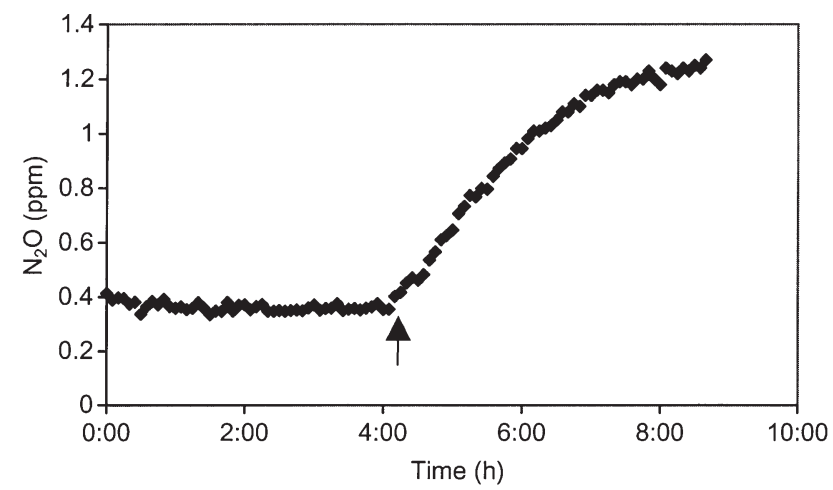

Fig. 3. Response of $\mathrm{N}_{2} \mathrm{O}$ concentrations to ammonium addition. Arrow indicates the addition of ammonium to a final concentration of $500 \mu \mathrm{M}$
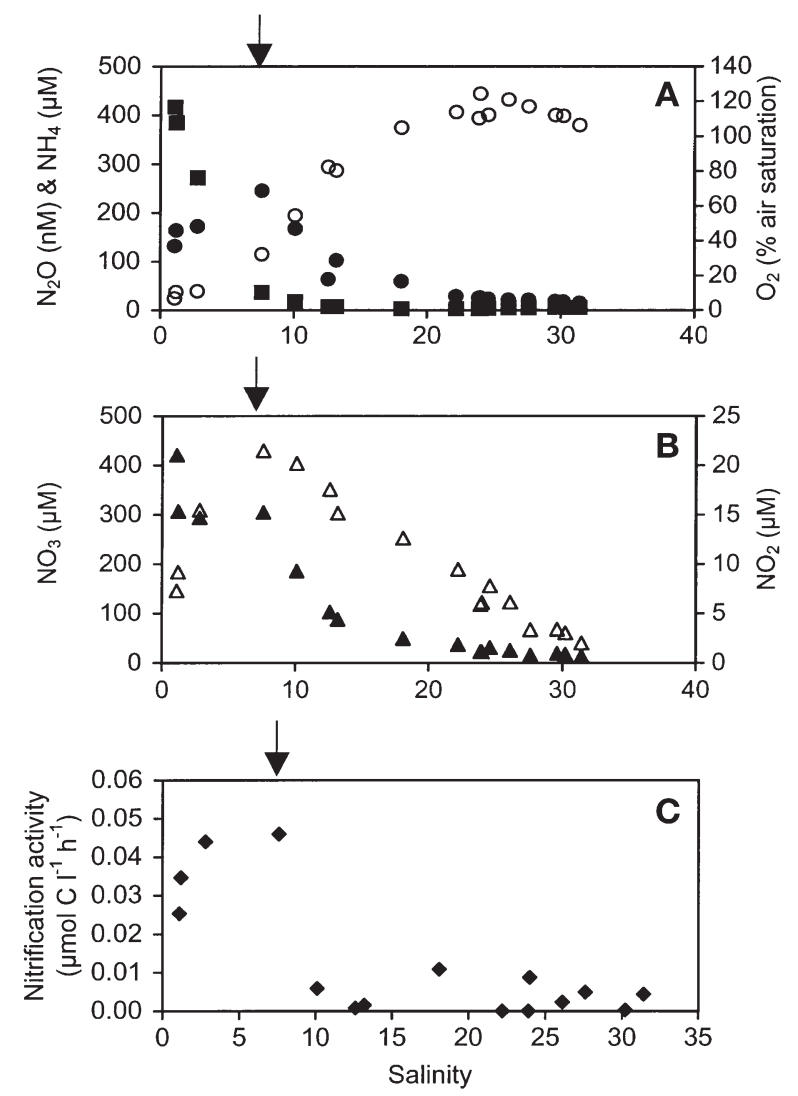

Fig. 4. Property versus salinity plots for the Schelde estuary in April 1997. (A) Oxygen (O), ammonium (घ) and $\mathrm{N}_{2} \mathrm{O}$ concentration $(\bullet)$; (B) nitrate $(\boldsymbol{\Delta})$ and nitrite concentration $(\mathbf{\Delta})$; (C) nitrification activity $(\bullet)$. The arrow indicates the location of the $\mathrm{N}_{2} \mathrm{O}$ peak

\section{Field observations}

The Schelde estuary is a highly heterotrophic system with low oxygen levels and high $\mathrm{N}$ loading. Fig. 4 shows a detailed set of longitudinal profiles for April 
1997. Ammonium concentrations were highest in the river Schelde $(417 \mu \mathrm{M})$ and rapidly decreased with increasing salinity (Fig. 4A). This decrease in ammonium concentration was accompanied by a proportional increase in nitrate from $146 \mu \mathrm{M}$ in the river to a maximum of $429 \mu \mathrm{M}$ at salinity 7.6 (Fig. 4B). At higher salinities, nitrate concentrations decreased again due to dilution with relatively nitrate-poor North Sea water. Nitrification activity was highest $\left(0.025 \mu \mathrm{mol} \mathrm{C} \mathrm{l}^{-1} \mathrm{~h}^{-1}\right)$ in the riverine samples and increased downstream to a

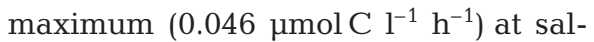
inity 7.6. Nitrification activities rapidly dropped further downstream (Fig. 4C). Oxygen saturation levels were below $20 \%$ in the low-salinity zone with high nitrification activities, while oxygen was supersaturated in the lower estuary due to a spring bloom. Nitrification of ammonium to nitrate in the low-salinity, low-oxygen zone was very likely incomplete because there was significant production of nitrite (uniform concentration of $15 \mu \mathrm{M}_{i}$ Fig. $4 \mathrm{~B}$ ) and $\mathrm{N}_{2} \mathrm{O}$ (245 nM at salinity 7.6; Fig. 4A).

This basic pattern of oxygen and nitrogen species was consistently observed over the 13 mo period of observation (Fig. 5), although concentration levels and profile shapes varied in response to variability in river discharge, temperature and other environmental factors. Ammonium concentration in the upper estuary varied from $86 \mu \mathrm{M}$ in September to $483 \mu \mathrm{M}$ in November. Concentrations of $\mathrm{N}_{2} \mathrm{O}$ in the tidal river varied between $8.7 \mathrm{nM}$ in November and 1457 nM in August. $\mathrm{N}_{2} \mathrm{O}$ showed prominent peaks in the period April until September with maximum concentrations during August. For all samples but the river in November, the estuary was a net source of $\mathrm{N}_{2} \mathrm{O}$ to the atmosphere with a median saturation ratio (observed/ equilibrium concentration) of 7.1 (atmospheric equilibrium levels varied from 6.9 to $14 \mathrm{nM})$. In accordance with the experimental results (Fig. 2A), $\mathrm{N}_{2} \mathrm{O}$ concentrations were related to oxygen levels in a non-linear way with peak concentrations of $\mathrm{N}_{2} \mathrm{O}$ at oxygen saturation levels between about 2 and $15 \%$, and lower $\mathrm{N}_{2} \mathrm{O}$ concentration above and below this oxygen level (Fig. 2B).

Ammonium concentrations in the Gironde estuary varied from 0.4 to $1.6 \mu \mathrm{M}$ with no clear trend with salinity (Fig. 6A). Oxygen increased from $65 \%$ saturation in the river to close to saturation in the most saline part. $\mathrm{N}_{2} \mathrm{O}$ concentrations are relatively low and varied from 9.8 to $36.7 \mathrm{nM}$, consistent with observations by Bange et al. (1996) and Abril et al. (2000). Ammonium concentrations in the Loire estuary were also relatively low ( 2 to $5.5 \mu \mathrm{M}$ ). Oxygen concentration in the Loire estuary were rather low with 2 oxygen minimum zones, one down to $21 \%$ saturation at salinity 7.5 and one down to $45 \%$ saturation at salin-
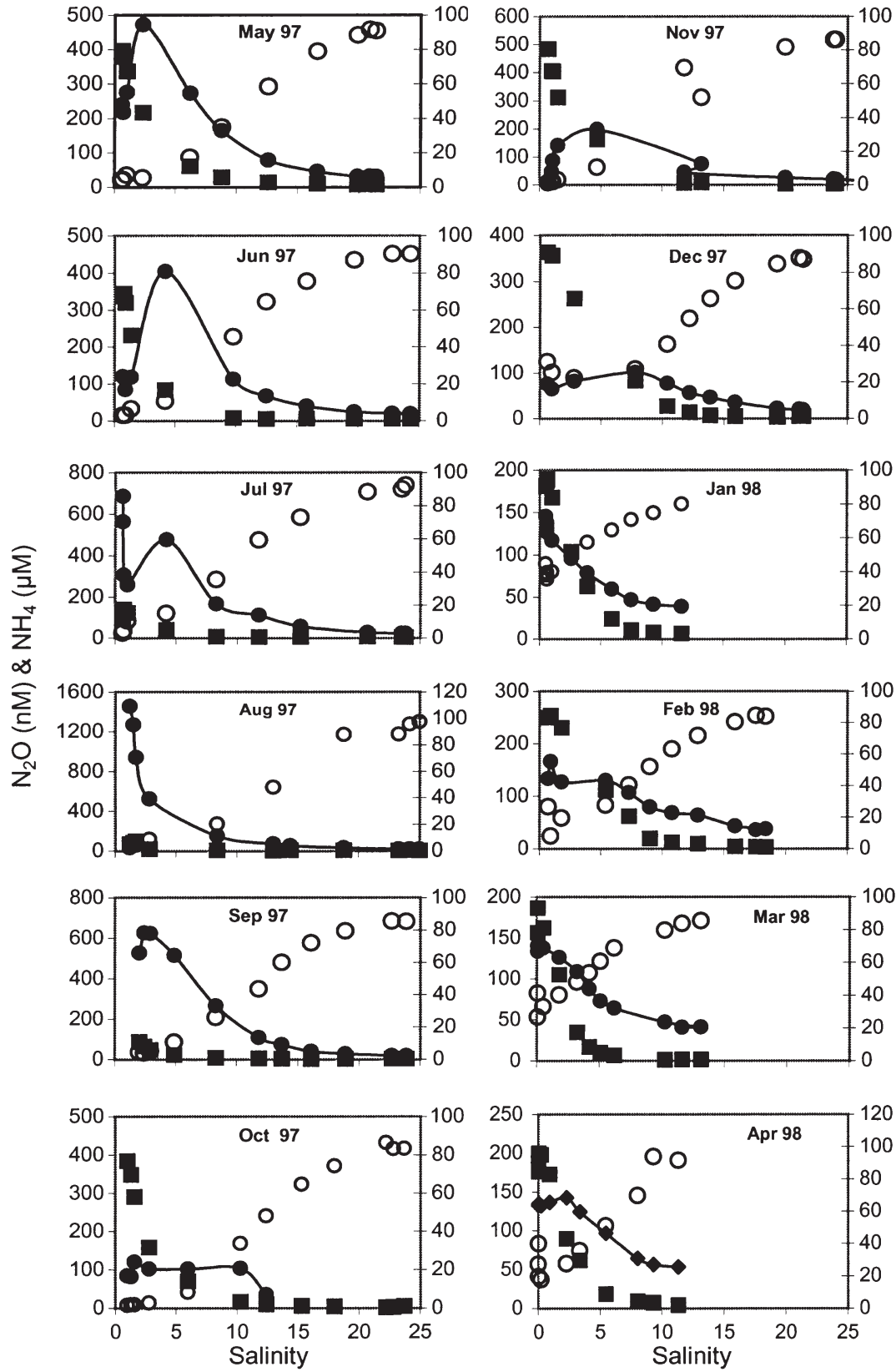

Fig. 5. Ammonium ( $(\mathbf{\square})$, oxygen $(\mathbf{O})$ and $\mathrm{N}_{2} \mathrm{O}(\bullet)$ versus salinity in the Schelde estuary from May 1997 to April 1998. Notice the differences in scale 


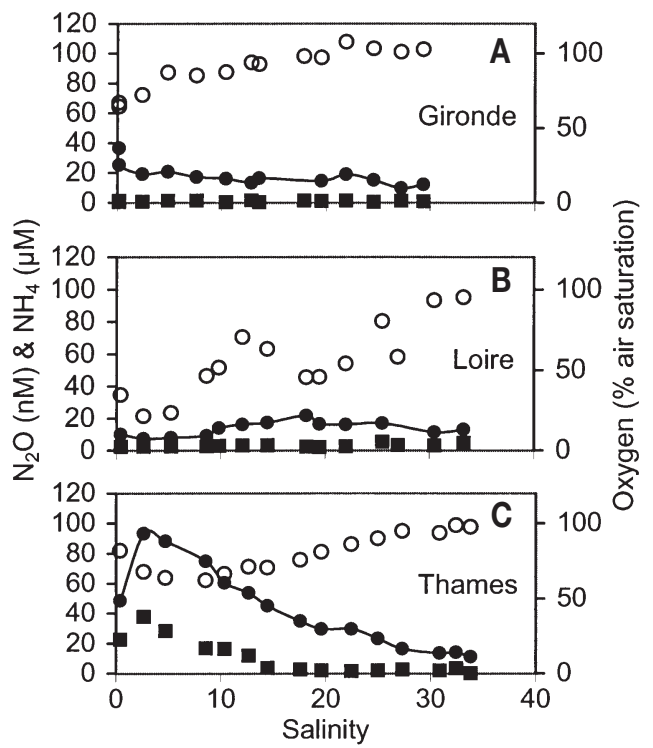

Fig. 6. Ammonium (घ), oxygen (o) and $\mathrm{N}_{2} \mathrm{O}(\bullet)$ versus salinity in the Gironde (A), Loire (B) and Thames (C) estuaries. Surface samples were taken in June 1997, September 1998 and February 1999 respectively

ity 18 to 20 (Fig. 6B). $\mathrm{N}_{2} \mathrm{O}$ concentrations were rather low ( 7.3 to $21 \mathrm{nM})$, but showed a maximum in the oxygen minimum zone at salinity 18 to 20 (Fig. 6B). Ammonium concentrations in the river Thames and upper part of the estuary were high (30 to $43 \mu \mathrm{M}$ ) but decreased rapidly with increasing salinity (Fig. 6C). Oxygen concentrations were lowest in the upper estuary but were always above $50 \%$ saturation. $\mathrm{N}_{2} \mathrm{O}$ concentration ranged from $49 \mathrm{nM}$ in the river to a maximum of $93 \mathrm{nM}$ at salinity 2.7 and then steadily decreased down to $11.2 \mathrm{nM}$ in the mouth of the estuary (Fig. 6C).

\section{DISCUSSION}

Concentrations of dissolved $\mathrm{N}_{2} \mathrm{O}$ are the result of production as well as consumption in the water bodies, inputs from the sediments, outgassing to the atmosphere and dispersal. Our data clearly revealed distinct $\mathrm{N}_{2} \mathrm{O}$ maxima in the Schelde estuary indicating either that $\mathrm{N}_{2} \mathrm{O}$ is locally produced or that there are large local inputs from the sediments. Robinson et al. (1998) and Dong et al. (2002) have reported that benthic denitrification represents the major source of $\mathrm{N}_{2} \mathrm{O}$ in the nitrate-rich Colne estuary. Sediment release could be a major source of $\mathrm{N}_{2} \mathrm{O}$ in the Schelde estuary as well. However, $\mathrm{N}_{2} \mathrm{O}$ maxima move along with the tides consistent with a water-column source. Middelburg et al. (1995) reported $\mathrm{N}_{2} \mathrm{O}$ fluxes from exposed intertidal sediments of the Schelde estuary. These sedimentary fluxes are highly variable but at least about 1 order of magnitude too low to sustain the flux of $\mathrm{N}_{2} \mathrm{O}$ from the water (De Wilde \& De Bie 2000). There are unfortunately no data for $\mathrm{N}_{2} \mathrm{O}$ release from inundated intertidal or subtidal sediment in the Schelde estuary.

High $\mathrm{N}_{2} \mathrm{O}$ concentrations in the Schelde estuary were consistently observed over a restricted range of salinity, which is also the zone of oxygen depletion (Figs. 4 \& 5). This might suggest that salinity could be the controlling factor of $\mathrm{N}_{2} \mathrm{O}$ production. In a previous study, we discussed this possibility while comparing our data with $\mathrm{N}_{2} \mathrm{O}$ measurements from 1978 (De Wilde $\&$ De Bie 2000). At that time, the oxygen-depleted zone of the estuary was more extensive and the $\mathrm{N}_{2} \mathrm{O}$ peak was observed at a higher salinity (i.e. more downstream), but at the same oxygen concentration. This indicates that salinity is more an indicator of the reaeration status of the estuarine water rather than that there is a direct effect of salt concentration on $\mathrm{N}_{2} \mathrm{O}$ production.

An oxygen control of $\mathrm{N}_{2} \mathrm{O}$ production is also consistent with most of the literature observations (Codispoti et al. 1992, 2001). Experimental studies with pure cultures (Goreau et al. 1980, Anderson et al. 1993, Kester et al. 1997) and suspended marine sediments (Jørgensen et al. 1984) have clearly shown maximum $\mathrm{N}_{2} \mathrm{O}$ production at a narrow range of low, but non-0 oxygen levels. We found similar results in the experiment with the natural estuarine population (Fig. 2A) as well as in our field observations (Fig. 2B). On the basis of these $\mathrm{N}_{2} \mathrm{O}$-oxygen relationships alone, it is difficult to conclude whether $\mathrm{N}_{2} \mathrm{O}$ production in the natural population is the result of nitrification or denitrification. Addition of acetylene resulted in complete inhibition of $\mathrm{N}_{2} \mathrm{O}$ production above $1 \%$ oxygen saturation, indicating that the $\mathrm{N}_{2} \mathrm{O}$ produced above this oxygen concentration is the product of nitrification. Moreover, addition of ammonium to natural communities resulted in higher $\mathrm{N}_{2} \mathrm{O}$ concentrations consistent with a nitrification source (Fig. 3). The importance of nitrification as a source of $\mathrm{N}_{2} \mathrm{O}$ has also been shown in the Humber estuary through quantification of the transformation of ${ }^{15} \mathrm{~N}$-labelled ammonium into ${ }^{15} \mathrm{~N}$-labelled $\mathrm{N}_{2} \mathrm{O}$ (Barnes \& Owens 1998).

A consortium of ammonia- and nitrite-oxidising bacteria carries out the complete process of nitrification. Nitrite-oxidising bacteria usually have a lower affinity for oxygen- than ammonia-oxidising bacteria (Laanbroek et al. 1994), which may then lead to the transient accumulation of nitrite at low oxygen levels (Fig. 4B; Helder \& De Vries 1983). Since nitrite and $\mathrm{N}_{2} \mathrm{O}$ can both be formed during nitrification at low oxygen levels, one might expect a correlation. They are indeed correlated $\left(\mathrm{r}^{2}=0.42, \mathrm{n}=146\right)$, but interpretation of this correlation is not simple, because of the escape of the $\mathrm{N}_{2} \mathrm{O}$ gas into the atmosphere. Moreover, nitrite and 
$\mathrm{N}_{2} \mathrm{O}$ are also intermediates in denitrification, and with the data at hand, we cannot exclude some contributions by this process.

When comparing oxygen concentrations at which $\mathrm{N}_{2} \mathrm{O}$ is produced in laboratory experiments (Figs. 1 \& 2A) and in estuaries (Figs. 2B, 4, 5 \& 6), it is clear that the $\mathrm{N}_{2} \mathrm{O}$ peaks in the field are occurring at higher oxygen concentrations than in the laboratory experiment. Maximum $\mathrm{N}_{2} \mathrm{O}$ levels in the Schelde estuary were observed at in situ oxygen concentrations in the range from 5 to $35 \mu \mathrm{M}$ ( 2 to $15 \%$ air saturation; Figs. 2B, 4 \& 5), while this range was more restricted and at a lower level in the laboratory experiment ( 2 to $7 \mu \mathrm{M}$; 0.5 to $2 \%$ air saturation). Maximum $\mathrm{N}_{2} \mathrm{O}$ concentrations in the Thames, Loire and Gironde estuaries occurred at even higher oxygen saturation levels (Fig. 6).

In our incubations, we vigorously stirred our water samples to optimise gas exchange between water and the headspace that was analysed. This stirring also inhibited the development of suboxic microsites so that all micro-organisms most likely experienced nearly the same, imposed oxygen level. Oxygen concentrations measured in estuarine waters are not necessarily representative for the microsites at which $\mathrm{N}_{2} \mathrm{O}$ formation might occur, e.g. in flocculate material or in fluid mud layers (Abril et al. 2000). Anoxic microsites in the abundant flocculate material have been proposed as the site for denitrification in the Schelde estuary (Soetaert \& Herman 1995) and suboxic microsites may thus provide niches for $\mathrm{N}_{2} \mathrm{O}$ production. The structure of flocculate material is readily destroyed by experimental manipulation and was certainly destroyed in our experiments. The Loire and Gironde estuaries are characterised by the temporal presence of dynamic, biogeochemical active fluid mud layers (Abril et al. 2000). These fluid mud layers are partly anoxic and suboxic, and have been shown to be a site of $\mathrm{N}_{2} \mathrm{O}$ production, nitrification and denitrification (Abril et al. 2000). Erosion of these mud layers and dispersal of the produced $\mathrm{N}_{2} \mathrm{O}$ would account for the observed $\mathrm{N}_{2} \mathrm{O}$ distribution. Both the abundance of flocculate materials and fluid mud layers are maximal in the maximum turbidity zone of estuaries (Herman \& Heip 1999) and could explain the correlation between $\mathrm{N}_{2} \mathrm{O}$ and turbidity in the Humber estuary (Barnes \& Owens 1998).

On the basis of our results, we propose the following mechanism for $\mathrm{N}_{2} \mathrm{O}$ production in estuarine waters. Nitrifying bacteria travelling in the estuary may be oxygen-limited in the upstream part, where ammonium concentrations are high (De Bie et al. 2002). As a consequence of estuarine mixing there is aeration and oxygen concentrations increase. Once the oxygen concentration has reached a level at which ammonium oxidation can occur, nitrifying bacteria turn active (Billen et al. 1985) and nitrite accumulates in the water, because of the low affinity for oxygen of nitrite-oxidising bacteria (Helder \& De Vries 1983). Since the oxygen concentration is still sub-optimal for ammonium oxidation, part of the oxidation products is released in the form of $\mathrm{N}_{2} \mathrm{O}$. More downstream in the estuary, when oxygen has further increased, the nitrification reaction is carried out more completely, as indicated by increasing nitrate concentrations, and decreasing ammonium and nitrite concentrations. $\mathrm{N}_{2} \mathrm{O}$ formation is reduced, and the $\mathrm{N}_{2} \mathrm{O}$ in the water is either emitted into the atmosphere or consumed by other processes in the water or sediment and diluted with seawater (Barnes \& Owens 1998). This mechanism is perfectly illustrated by the Schelde data (Figs. 4 \& 5) and may also apply to the Thames estuary (Fig. 6). When ammonium concentrations are too low, like in the Gironde and Loire, $\mathrm{N}_{2} \mathrm{O}$ does not reach high levels. When oxygen concentrations are very low, i.e. during summer conditions in the upper Schelde estuary (Fig. 5) or in the fluid muds of the Gironde estuary (Abril et al. 2000), nitrification is oxygen-limited and denitrification of nitrate may cause additional $\mathrm{N}_{2} \mathrm{O}$ production. Denitrification based $\mathrm{N}_{2} \mathrm{O}$ production may be substantial given that maximum $\mathrm{N}_{2} \mathrm{O}$ concentration occur during the summer period with low oxygen conditions.

Although our study has clearly revealed that oxygen is the major factor controlling $\mathrm{N}_{2} \mathrm{O}$ in estuarine systems, it is not in conflict with the conceptual nitrogen loading model of Seitzinger \& Kroeze (1998). Integrated over large spatial and temporal domains, there are always areas in or periods during which oxygen supply is limited and denitrification occurs, i.e. in estuarine and coastal sediments that are rich in labile carbon. In coastal sediments, denitrification, and consequently $\mathrm{N}_{2} \mathrm{O}$ production, is primarily limited by bottom-water nitrate concentrations either directly (nitrate influxes) or indirectly via enhancement of the nitrification-denitrification coupling efficiency (Middelburg et al. 1996). $\mathrm{N}_{2} \mathrm{O}$ in estuarine systems with oxygenated water columns then depends on the nitrate and/or nitrite concentration in the water that affects $\mathrm{N}_{2} \mathrm{O}$ production processes in sediments (e.g. the Colne estuary in the UK, Robinson et al. 1998, Dong et al. 2002) or in fluid mud layers (e.g. the Gironde estuary in France; Abril et al. 2000). In estuarine systems with low watercolumn oxygen concentrations, there is additional $\mathrm{N}_{2} \mathrm{O}$ formation resulting from nitrification, which is controlled primarily by oxygen and ammonium availability. Moreover, in the complete absence of oxygen, there may be denitrification and $\mathrm{N}_{2} \mathrm{O}$ formation in the water column. There appear to be multiple controlling factors: nitrate availability for benthic $\mathrm{N}_{2} \mathrm{O}$ production during denitrification and oxygen (and ammonium and nitrate) for pelagic $\mathrm{N}_{2} \mathrm{O}$ production during nitrification and denitrification, respectively. These processes are 
not exclusive but additive and may alternate in their relative importance depending on the system, the season and tidal cycle. This may then explain why Cole \& Caraco (2001) found only a weak correlation between average nitrate concentrations and $\mathrm{N}_{2} \mathrm{O}$ fluxes across a number of estuarine systems.

In conclusion, this study has identified the non-linear relation between low oxygen concentration and $\mathrm{N}_{2} \mathrm{O}$ production by nitrifying bacteria, both in the field and experimentally. The combination of low oxygen conditions with high nitrogen loads is not uncommon in estuaries and other dynamic coastal systems, which illustrates the importance of estuaries as a source of $\mathrm{N}_{2} \mathrm{O}$.

Acknowledgements. We thank Joop Nieuwenhuize for assistance with nitrous oxide measurements, Hein de Wilde for kindly providing us the gas-tight incubation vessels, Marc Staal for help with gas flow controllers, and our BIOGEST colleagues for sharing water samples and providing data as well as a pleasant, stimulating scientific climate. We thank Louis Codispoti, Gwen Abril and an anonymous reviewer for constructive comments. This research has been supported by the EU (BIOGEST, ENV4-CT96-0213 and EUROTROPH, EVK3CT-2000-00040). This is publication 2990 of the Netherlands Institute of Ecology, Royal Netherlands Academy of Arts and Sciences.

\section{LITERATURE CITED}

Abril G, Riou SA, Etcheber H, Frankignoulle M, De Wit R, Middelburg JJ (2000) Transient, tidal time-scale, nitrogen transformations in an estuarine turbidity maximum-fluid mud system (The Gironde, South-west France). Estuar Coast Shelf Sci 50:703-715

Anderson IC, Levine JS (1986) Relative rates of nitric oxide and nitrous oxide production by nitrifiers, denitrifiers and nitrate respirers. Appl Environ Microbiol 51(5):938-945

Anderson IC, Poth M, Homstead J, Burdige D (1993) A comparison of $\mathrm{NO}$ and $\mathrm{N}_{2} \mathrm{O}$ production by the autotrophic nitrifier Nitrosomonas europaea and the heterotrophic nitrifier Alcaligenes faecalis. Appl Environ Microbiol 59: 3525-3533

Bange HW (2000) It's not a gas. Nature 408:301-302

Bange HW, Rapsomanakis S, Andreae MO (1996) Nitrous oxide in coastal waters. Global Biochem Cycles 10(1): 197-207

Barnes J, Owens NJP (1998) Denitrification and nitrous oxide concentrations in the Humber estuary, UK, and adjacent coastal zones. Mar Pollut Bull 37:247-260

Battle M, Bender M, Sowers T, Tans PP and 7 others (1996) Atmospheric gas concentrations over the past century measured in air from firn at the South Pole. Nature 383: 231-235

Betlach MR, Tiedje JM (1981) Kinetic explanation for accumulation of nitrite, nitric oxide, and nitrous oxide during denitrification. Appl Environ Microbiol 42(6):1074-1084

Billen G, Somville M, De Becker E, Servais P (1985) A nitrogen budget of the Scheldt hydrographical basin. Neth J Sea Res 19(3/4):223-230

Codispoti LA, Elkins JW, Yoshinar T, Friederich GE, Sakamoto LM, Packard TT (1992) On the nitrous oxide flux from productive regions that contain low oxygen waters. In: Desai BN (ed) Oceanography of the Indian Ocean. Oxford and IBH, New Delhi, p 271-284

Codispoti LA, Brandes JA, Christensen JP, Devol AH, Naqvi SWA, Paerl HW, Yoshinari T (2001) The oceanic fixed nitrogen and nitrous oxide budgets: moving targets as we enter the anthropocena? Sci Mar 65:85-105

Cole JJ, Caraco NF (2001) Emissions of nitrous oxide $\left(\mathrm{N}_{2} \mathrm{O}\right)$ from a tidal, freshwater river, the Hudson river, New York. Environ Sci Technol 35:991-996

De Bie MJM, Starink M, Boschker HTS, Peene J, Laanbroek HJ (2002) Nitrification in the Scheldt estuary: methodological aspects and factors influencing its activity. FEMS Microbiol Ecol (in press)

De Wilde HPJ, De Bie MJM (2000) Nitrous oxide in the Scheldt estuary: production by nitrification and emission to the atmosphere. Mar Chem 69:203-216

Dong LF, Nedwell DB, Underwood GJC, Thornton DCO, Rusmana I (2002) Nitrous oxide formation in the Colne estuary, England: the central role of nitrite. Appl Environ Microbiol 68:1240-1249

Goreau TJ, Kaplan WA, Wofsy SC, McElroy MB, Valois FW, Watson SW (1980) Production of $\mathrm{NO}_{2}{ }^{-}$and $\mathrm{N}_{2} \mathrm{O}$ by nitrifying bacteria at reduced concentrations of oxygen. Appl Environ Microbiol 40:526-532

Helder W, De Vries RTP (1983) Estuarine nitrite maxima and nitrifying bacteria (Ems-Dollard estuary). Neth J Sea Res 17(1):1-18

Herman PMJ, Heip CHR (1999) Biogeochemistry of the maximum turbidity zone of estuaries (MATURE): some conclusions. J Mar Syst 22:89-104

Hyman MR, Arp DJ (1987) Quantification and removal of some contaminating gases from acetylene used to study gas-utilizing enzymes and microorganisms. Appl Environ Microbiol 53:298-303

IPCC (Intergovernmental Panel on Climate Change) (1996) Climate change 1995. The science of climate change. Contribution of working group I to the second assessment report of the Intergovernmental Panel on Climate Change. Cambridge University Press, Cambridge

Jørgensen KS, Jensen HB, Sørensen J (1984) Nitrous oxide production from nitrification and denitrification in marine sediment at low oxygen concentrations. Can J Microbiol 30:1073-1078

Kester RA, De Boer W, Laanbroek HJ (1997) Production of NO and $\mathrm{N}_{2} \mathrm{O}$ by pure cultures of nitrifying and denitrifying bacteria during changes in aeration. Appl Environ Microbiol 63:3872-3877

Laanbroek HJ, Bodelier PLE, Gerards S (1994) Oxygen consumption kinetics of Nitrosomonas europaea and Nitrobacter hamburgensis grown in mixed continuous cultures at different oxygen concentrations. Arch Microbiol 161: 156-162

Middelburg JJ, Nieuwenhuize J (2000) Nitrogen uptake by heterotrophic bacteria and phytoplankton in the nitraterich Thames estuary. Mar Ecol Prog Ser 203:13-21

Middelburg JJ, Klaver G, Nieuwenhuize J, Markusse RM, Vlug T, Van der Nat FJWA (1995) Nitrous oxide emissions from estuarine intertidal sediments. Hydrobiologia 311: $43-55$

Middelburg JJ, Soetaert K, Herman PMJ, Heip CHR (1996) Denitrification in marine sediments: a model study. Global Biochem Cycles 10:661-673

Middelburg JJ, Nieuwenhuize J, Iversen N, Hoegh N, De Wilde HPJ, Helder W, Seifert R, Christof O (2002) Methane distribution in European tidal estuaries. Biogeochem 59(April/May):95-119 
Naqvi SWA, Jayakumar DA, Narvekar PV, Naik H, Sarma VVSS, D'Souza W, Joseph S, George MD (2000) Increased marine production of $\mathrm{N}_{2} \mathrm{O}$ due to intensifying anoxia on the Indian continental shelf. Nature 408:346-349

Robinson AD, Nedwell DB, Harrison RM, Ogilvie BG (1998) Hypernutrified estuaries as sources of $\mathrm{N}_{2} \mathrm{O}$ emission to the atmosphere: the estuary of the river Colne, Essex, UK. Mar Ecol Prog Ser 164:59-71

Seitzinger SP, Kroeze C (1998) Global distribution of nitrous oxide production and $\mathrm{N}$ inputs in freshwater and coastal marine ecosystems. Global Biochem Cycles 12:93-113

Seitzinger SP, Nixon SW (1985) Eutrophication and the rate of denitrification and $\mathrm{N}_{2} \mathrm{O}$-production in coastal marine sediments. Limnol Oceanogr 30(6):1331-1339

Soetaert K, Herman PMJ (1995) Nitrogen dynamics in the WesterScheldt estuary (SW Netherlands) estimated by means of the ecosystem model MOSES. Hydrobiologia 311:225-246

Editorial responsibility: Otto Kinne,

Oldendorf/Luhe, Germany
Somville M (1978) A method for the measurement of nitrification rates in water. Water Res 12:843-848

Stüven R, Vollmer M, Bock E (1992) The impact of organic matter on nitric oxide formation by Nitrosomonas europaea. Arch Microbiol 158:439-443

Trimmer M, Nedwell DB, Sivyer DB, Malcolm SJ (2000) Seasonal benthic organic matter mineralisation measured by oxygen uptake and denitrification along a transect of the inner and outer river Thames estuary, UK. Mar Ecol Prog Ser 197:103-119

Weiss RF, Price BA (1980) Nitrous oxide solubility in water and seawater. Mar Chem 8:347-359

Yoh M, Terai H, Saijo Y (1983) Accumulation of nitrous oxide in the oxygen deficient layer of freshwater lakes. Nature 301:327-329

Zumft WG, Kroneck PMH (1990) Metabolism of nitrous oxide. In: Revsbech NP, Sørensen J (eds) Denitrification in soil and sediment. Plenum Press, New York, p 37-55

Submitted: November 19, 2001; Accepted: May 24, 2002

Proofs received from author(s): August 22, 2002 